\title{
Грузинский сорт винограда Грубелла в условиях Нижнего Придонья
}

Валентина Алексеевна Ганич, канд. с.-х. наук, ведущий научный сотрудник лаборатории ампелографии, ganich1970@yandex.ru;

Людмила Георгиевна Наумова, канд. с.-х. наук, ведущий научный сотрудник лаборатории ампелографии,

LGnaumova@yandex.ru;

Наталья Викторовна Матвеева, старший научный сотрудник лаборатории технологии виноделия, n-matvеevа78@ mail.ru

Всероссийский научно-исследовательский институт виноградарства и виноделия имени Я.И. Потапенко - филиал Федерального государственного бюджетного научного учреждения «Федеральный Ростовский аграрный научный центр», Россия, 346421, Ростовская обл., г. Новочеркасск, пр. Баклановский, 166

В статье приведены результаты агробиологического и технологического изучения аборигенного грузинского сорта винограда технического направления использования Грубелла в сравнении с контрольным сортом Сибирьковый. Исследования проводились в 2016-2018 гг. на Донской ампелографической коллекции им. Я.И. Потапенко (в условиях Нижнего Придонья) по общепринятым в виноградарстве методикам. Сорта изучались в укрывной, привитой культуре (подвой Берландиери х Рипариа Кобер 5ББ). Схема посадки кустов 3,0 х 1,5 м. Культура неполивная. По проценту распустившихся почек, средней массе грозди и урожайности сорт Грубелла превосходит контрольный сорт. В опытных виноматериалах определяли физико-химические показатели (спиртуозность, массовую концентрацию титруемых и летучих кислот, сахаров, приведенного экстракта, диоксида серы). Все эти показатели соответствовали требованиям ГОСТ. Вино из сорта Грубелла было бледно-соломенного цвета, с зеленоватым оттенком, аромат богатый, с тонами полевых цветов и медово-пряными оттенками. Вкус содержательный, свежий, долгое приятное послевкусие. Высокая дегустационная оценка изучаемого сорта (8,8 балла) на уровне контрольного сорта Сибирьковый подтверждает целесообразность использования сорта Грубелла для приготовления столовых вин высокого качества. Анализ полученных данных позволил сделать заключение о том, что в данных условиях произрастания грузинский сорт Грубелла по качеству вина не уступает контрольному сорту, а по урожайности превосходит его. Поэтому мы считаем, что сорт требует дальнейшего углубленного изучения и создания технологии, позволяющей максимально раскрыть потенциал сорта и получить качественное вино с высокими органолептическими показателями. Рекомендуется использовать сорт Грубелла для селекции с целью создания технических сортов с высокими технологическими свойствами.

Ключевые слова: ампелографическая коллекция; виноград; сорт; фенология; урожайность; дегустационная оценка вина; кондиции урожая.
O R I G I N A L A R T I C L E

\section{Georgian grapevine variety 'Grubella' in the conditions of the Lower Don region}

Valentina Alekseevna Ganich, Lyudmila Georgievna Naumova, Natal'ya Viktorovna Matveeva

All-Russian Research Institute named after Ya.I. Potapenko for Viticulture and Winemaking - branch of Federal State Budget Scientific Institution «Federal Rostov Agricultural Research Center», 166 Baklanovsky Ave., 346421 Novocherkassk, Rostov region, Russian Federation

The paper reports on the findings of agro-biological and technological study of native Georgian wine grapevine variety 'Grubella' in comparison with control cultivar 'Sibirkovyi'. The study involved standard methods for viticulture and was carried out in 2016-2018 at Ya.I. Potapenko Don Ampelographic collection (in the Lower Don region). The varieties were studied in earth-covered, grafted culture (rootstock 'Berlandieri' x 'Riparia Cober 5BB'). The planting scheme was $3.0 \times 1.5 \mathrm{~m}$. Non-irrigated culture. By percentage of evolved buds, the average bunch weight and yield 'Grubella' variety exceeded the control. The test wine materials were analyzed for physical and chemical parameters (alcohol strength, mass concentration of titrated and volatile acids, sugars, reduced extract, and sulfur dioxide). All the indicators met the requirements of the State standards. The wine made of 'Grubella' grapes was pale straw-coloured, with a greenish tinge, and had rich aroma with tones of wild flowers and honey-spicy overtones. The taste was rich, fresh, with a long pleasant aftertaste. The high tasting score received by the studied variety ( 8.8 points) was at the same level as the score of the control variety 'Sibirkovyi', which confirms the suitability of 'Grubella' grapes for the production of high quality table wines. Data analysis suggests that under the given growing conditions the Georgian grapevine variety 'Grubella' equals the control variety in the quality of wine, surpassing it in terms of the yield. We therefore believe that the variety is worth further in-depth study, and requires technology development in order to reveal its potential and obtain high-quality wine with high organoleptic characteristics. 'Grubella' variety is recommended for breeding with a view to generate technical varieties with high technological properties.

Key words: ampelographic collection; grapes; cultivar; phenology; productivity; tasting evaluation of wines; harvest characteristics.

\section{Как цитировать эту статью:}

Ганич В.А., Наумова Л.Г., Матвеева Н.В. Грузинский сорт винограда Грубелла в условиях Нижнего Придонья // «Магарач». Виноградарство и виноделие, 2019; 21(2). С. 92-96. DOI 10.35547/IM.2019.21.2.002

\section{How to cite this article:}

Ganich V.A., Naumova L.G., Matveeva N.V. Georgian grapevine variety 'Grubella' in the conditions of the Lower Don region. Magarach. Viticulture and Winemaking, 2019; 21(1); pp. 92-96. DOI 10.35547/IM.2019.21.2.002

УДК: 634.85:631.524.022/.85(470.61)

Поступила 24.03.2019

Принята к публикации 16.05.2019

(C) Авторы, 2019
$\mathrm{B}$ ведение. Мобилизация, сохранение и изучение генетических ресурсов на колмекциях направлены на решение фундаментальных и прикладных задач, среди которых систематика и таксономия, моделирование экологических ниш, биогеография и Ар. [1-4].

Комлекции сельскохозяйственных растений успешно ис-

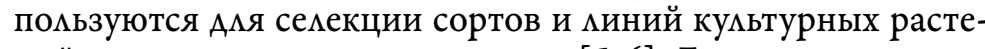
ний, интродукции новых культур [5-6]. Биоресурсные колмекции (БРК) также активно используют в образовании [7]. Их актуальность в решении научных и прикцадных задач осознана относительно недавно, что привело к росту работ по систематическому пополнению, каталогизации и оцифровке БРК [8-9].

Учеными многих стран Аоказано, что мобимизация сортовых ресурсов винограда в ампелографических комлекци- 


\section{ВИНОГРАДАРСТВО}

Грузинский сорт винограда Грубельа

в условиях Нижнего Придонья

ях играет важную роль в сохранении и использовании генофонда винограда, большинство аборигенных и мацораспространенных сортов винограда в настоящее время сохранимось только благодаря комиекциям [10-20].

ОАна из важных задач сбора и сохранения генофонда рода Vitis во многих странах мира - сохранение местных сортов винограда, которые являются искиючительно частью природного наслеАия и не произрастают в Аругих винных регионах [21-23].

Аборигенные, стародавние сорта винограда размичных регионов возделывания, как и дикие формы наиболее ценная часть мирового генофонда культуры. Именно в генотипах автохтонных сортов винограда могут быть выявлены комплексы признаков, обеспечивающие аАаптивность растений к конкретным агрокмиматическим условиям возАелывания [24].

В Аонской ампелографической комлекции им. Я.И. Потапенко (ВНИИВиВ - фимиал ФГБНУ ФРАНЦ) собран значитецьный генофонА сортов винограда из разных районов возделывания: Аон - 61, Аагестан 50, Крым - 31, Республика Молдова - 61, Узбекистан - 43, Франция - 40, Грузия - 39, Венгрия - 34 и Ар. [15].

Изучение генофонда аборигенных сортов винограда в последние годы во всем мире является актуацьным [25-27]. Аборигенные сорта не только изучаются, но и используются в селекции при выведении новых сортов винограда. На протяжении XX столетия в грузинских и зарубежных семекционных программах Аостаточно широко были привлечены автохтонные грузинские сорта винограда - Саперави, Ркацители, Тавквери, Аодремяби, Чинури, Мцване кахетинский и Ар. С их участием выведено 193 новых сорта разцичного направцения использования в АзербайАжане, Армении, Венгрии, Грузии, Кыргызстане, Республике Молдова, Узбекистане, Украине, Российской Федерации [28].

Грубемма (рис.) - грузинский сорт известен также под названием Грубемла курдзени, относится к эколого-географической группе сортов бассейна Черного моря.

Коронка молодого побега покрыта густым воймочным опушением, почти белая, со слабо-розовой каймой по краю.

Аист среАний, округлый ими слегка овацьный, пятицопастный, Аовоцьно глубоко рассеченный, с наличием вторичных вырезок (характерно Аля сорта). Пластинка $и$ ита пиоская, реже неопределенно изогнутая с отогнутыми вниз краями. Верхняя поверхность светмо-зеленая, мемкосетчато-морщинистая, иногАа почти гцадкая.

Верхние вырезки средние, реже глубокие, закрытые с широкоэмииптическим просветом, реже открытые, $\Lambda$ ировидные с узким устьем и заостренным Аном. Нижние вырезки мелкие или среАние, открытые мировидные, реже закрытые, с эмииптическим просветом и заостренным Аном.

Черешковая выемка открытая, мировидная, реже сводчатая, широкая, с округмым Аном. Зубчики на концах мопастей треугольные с выпукмыми сторонами и острой вершиной, реже купомовидные. Зубчики по

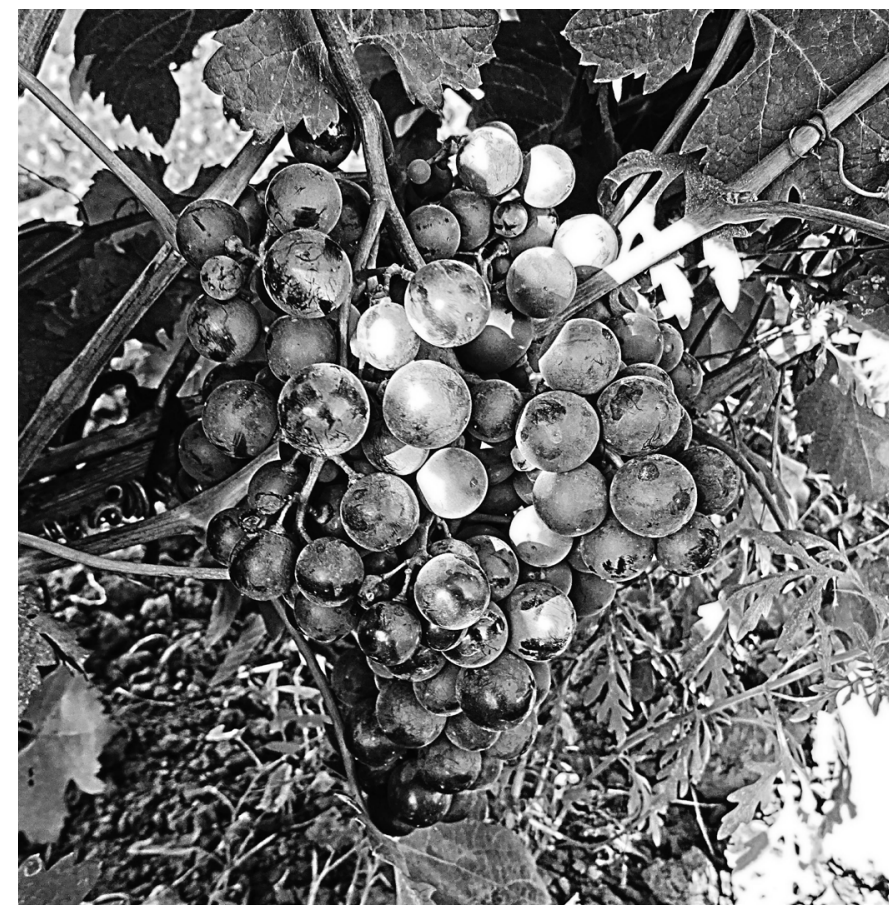

Рис. Гроздь сорта винограда Грубелла

Figure. A bunch of Grubella grapes

краю пиловидные с выпукиыми сторонами и острой вершиной. Опушение на нижней стороне миста слабое паутинистое, с подстилающим щетинистым пушком среАней густоты, у мистьев нижнего яруса щетинистое опушение значительно усиливается. Черешок короче среАинной жикки, реже равен ей, темно-зеленый или слабовинно-красный.

Цветок обоеполый. ГрозАь среАняя, иногАа Аовоцьно крупная, ширококоническая, реже циминАроконическая, мопастная, средней плотности, реже пиотная. Ягода средняя, округлая, слегка сплюснутая, серо-голубая с фиолетовым оттенком. Кожица тонкая, но прочная, покрыта обимьным восковым налетом. Мякоть сочная, распиывающаяся. Вкус приятный, без особого аромата. Семян в ягоде одно-четыре.

Сима роста кустов средняя. Вызревание мозы хорошее. Устойчивость к грибным заболеваниям среАняя. Используется Аля приготовления столовых вин [29].

Относится к универсацьным сортам среднего срока созревания.

Материалы и методы исследований. На Аонской ампемографической коммекции им. Я.И. Потапенко (г. Новочеркасск, Россия) в 2016 - 2018 гг. проведено сравнительное изучение аборигенных сортов винограда: грузинского - Грубемла и донского - Сибирьковый. Сорта изучались в укрывной привитой кумьтуре на подвое Берландиери х Рипариа Кобер 5ББ. Схема посаАки кустов 3,0 x 1,5 м. Кумьтура непомивная.

Комчекция расположена на степном придонском плато. Высота местности наА уровнем моря 90 м, рецьеф волнистый. Почвы преАставцены обыкновенными карбонатными черноземами, среднемощными, слабогумусированными, тяжелосуглинистыми на мессовидных суглинках. Не засолены, с высоким обеспечением усвояемыми формами фосфора, средним обеспечением подвижным кацием, обогащены кар- 
Georgian grapevine variety 'Grubella' in the conditions of the Lower Don region.

бонатами камьция. Мощность гумусового горизонта (A-B) Аостигает 90 см. Грунтовые воды залегают на глубине 15-20 м и Аця корней винограда недоступны.

Изучение сортов винограда проводими на комлекции с использованием общепринятых в виноградарстве методик [30-32]. Сахаристость сока ягод опреАемяни по ГОСТу 27198-87, титруемую кислотность - ГОСТ 32114-2013.

Образцы виноматериалов готовицись в маборатории технологии виноделия в условиях микровиноделия по кмассической технологии приготовления белых вин «Сборник технологических инструкций, правиц и нормативных материалов по винодемьческой промышленности» [33]. В опытных виноматериалах опредемями физико-химические показатеми в соответствии с ГОСТ 32030 2013 «Вина столовые и виноматериалы стомовые. Общие технические усмовия». В готовых винах определяли: объемную Аолю этимового спирта - ГОСТ 32095-2013, метучие кислоты - ГОСТ 32001-2012, общий АиоксиА серы - ГОСТ 32115-2013, приведенный экстракт - ГОСТ 32000-2012.

На закрытой дегустации была проведена оценка образцов вин Аегустационной комиссией, утвержАенной приказом Аиректора, в соответствии с ГОСТ 32051-2013.

Результаты исследований. Анализируя агробиомогические показатели изучаемых сортов (табц. 1) отмечаем, что распускание почек происходит одновременно, а дата помной зрецости ягоА у сорта Сибирьковый отмечена 6 сентября, а у сорта Грубемла - 16 сентября.

По срокам созревания сорт Грубемиа относиться к сортам среАне-позАнего срока созревания (147 Аней), а Сибирьковый - к сортам среднего срока созревания (137 Аней).

Процент распустившихся почек, среАняя масса грозАи, урожай с куста и урожайность у сорта Грубемла выше контромьного сорта Сибирьковый. Несмотря на то, что у сорта Грубемла низкие коэффициент плодоношения $(0,4)$ и процент плодоносных побегов $(30,1)$ урожайность от этого не снижается, за счет того, что сорт имеет крупные и очень крупные грозАи (отАельные грозАи бывают массой Ао 900 г).

Содержание сахаров и титруемых кисцот в соке ягоА при созревании находятся на одинаковом уровне (сахаристость - среАняя, кислотность - низкая).

В опытных виноматериалах опредемя$\Lambda$ и физико-химические показатели (табц. 2). Виноматериалы имели спиртуозность 11,9 - 12,3\% об., что говорит, о Аостаточном сахаронакопмении в ягодах. Такое содержание спирта способствует не тоцько высокому ка-
Ganich V.A., Naumova L.G.

Matveeva N.V.

VITICULTURE

Таблица 1. Агробиологические показатели сортов

Table 1. Agrobiological characteristics of varieties

\begin{tabular}{|c|c|c|}
\hline Показатеми & Грубем а & Сибирьковый \\
\hline Аата начама распускания почек & 23.04 & 23.04 \\
\hline Аата полной зрености ягоА & 16.09 & 06.09 \\
\hline Распустившихся почек, \% & 74,0 & 66,9 \\
\hline Пцодоносных побегов, \% & 30,1 & 62,5 \\
\hline Коэффициент пмодоношения & 0,4 & 1,0 \\
\hline Комичество нормацьно развитых побегов, шт. & 28 & 21 \\
\hline Средняя масса грозди, г & 432 & 186 \\
\hline Продуктивность побегов, г & 173 & 186 \\
\hline Урожайность, кг/куст & 4,8 & 3,9 \\
\hline Расчетная урожайность, т/га & 10,6 & 8,7 \\
\hline Аата хим. анамиза & 19.09 & 17.09 \\
\hline Сахаристость сока ягоА, г/100 см & 20,9 & 20,8 \\
\hline Титруемая кислотность, Г/АM & 5,7 & 6,4 \\
\hline $\begin{array}{l}\text { От начама распускания почек до полной зремо- } \\
\text { сти ягод: } \\
\text { количество Аней } \\
\text { сумма температур, }{ }^{\circ} \mathrm{C}\end{array}$ & $\begin{array}{l}147 \\
3275,1\end{array}$ & $\begin{array}{l}137 \\
3150,1\end{array}$ \\
\hline
\end{tabular}

Таблица 2. Химические показатели виноматериалов

Table 2. The chemical parameters of the wine materials

\begin{tabular}{|c|c|c|c|c|c|c|}
\hline \multirow[b]{2}{*}{$\begin{array}{l}\text { Виноматериал } \\
\text { из сорта }\end{array}$} & \multirow[b]{2}{*}{$\begin{array}{l}\text { Объемная } \\
\text { Аоця этимо } \\
\text { вого спир- } \\
\text { та, \% }\end{array}$} & \multicolumn{5}{|c|}{ Массовая концентрация } \\
\hline & & $\begin{array}{l}\text { титруемых } \\
\text { кисмот, } \\
\text { г/Ам }\end{array}$ & $\begin{array}{l}\text { метучих } \\
\text { кислот, } \\
\text { г/Ам }\end{array}$ & $\begin{array}{l}\text { caxa- } \\
\text { poB, } \\
\text { Г/AM }\end{array}$ & $\begin{array}{l}\text { приведен- } \\
\text { ного экс- } \\
\text { тракта, } \\
\text { г/Ам }\end{array}$ & $\begin{array}{l}\text { общего } \\
\text { АиоксиАа } \\
\text { серы, } \\
\text { мг/Aм }{ }^{3}\end{array}$ \\
\hline Грубем а & 12,3 & 5,7 & 0,44 & 1,0 & 22,5 & 34,6 \\
\hline Сибирьковый & 11,9 & 4,8 & 0,48 & 0,8 & 21,7 & 46,8 \\
\hline
\end{tabular}

честву вина, но и сохранению в Аацьнейшем его микробиологической стабимьности.

Массовая концентрация титруемых кислот в опытных виноматериалах находимась на уровне 4,8-5,7 г/Aм³ тельно отразимось на органолептической оценке вина.

Массовая концентрация метучих кислот в образцах была на уровне 0,4 г/Aм ${ }^{3}$ и не превышама предемов, Аопускаемых ГОСТ.

ПривеАенный экстракт виноматериацов преАставцен органическими кислотами, феномьными веществами, и Аругими нелетучими соеАинениями. Величина приведенного экстракта нормирована - это один из показателей кондиционности вина. В исследуемых образцах этот показатемь составим 21,7 $-22,5 \mathrm{r} / \mathrm{AM}^{3}$.

Показатели качества, такие как массовая концентрация сахаров и содержание общего диоксида серы, были в пределах нормы Аця качественной продукции.

ОАной из важных характеристик вина явцяется его органомептическая оценка (табц. 3). Высокая Аегустационная оценка изучаемого сорта (8,8 бамла) на уровне контромьного сорта Сибирьковый подтвержАает целесообразность использования сорта Грубемца Аця приготовцения столовых вин высокого качества.

Выводы. Классические сорта винограда в настоящее время Аостаточно хорошо изучены с целью получения высококачественных вин, разработаны технологии, которые учитывают 
ВИНОГРАДАРСТВО

Грузинский сорт винограда Грубельа

в условиях Нижнего Придонья

Таблица 3. Органолептическая характеристика и дегустационные оценки вин

Table 3. Organoleptic characteristics and tasting evaluation of wines

\begin{tabular}{|c|c|c|}
\hline Сорт & Органолептическая характеристика вина & $\begin{array}{l}\text { Аегустаци- } \\
\text { онная оценка } \\
\text { вина, бам }\end{array}$ \\
\hline Грубем а & $\begin{array}{l}\text { БлеАно-соломенного цвета, с зеленоватым } \\
\text { оттенком. Аромат богатый, с тонами полевых } \\
\text { цветов и меАово-пряными оттенками. Вкус } \\
\text { содержательный, свежий. Аолгое приятное } \\
\text { послевкусие. }\end{array}$ & 8,8 \\
\hline Сибирьковый & $\begin{array}{l}\text { Бледно - соломенного цвета. Аромат ярко } \\
\text { выражен, с тонами полевых трав и цветов. } \\
\text { Вкус полный, мягкий. Приятное послевкусие }\end{array}$ & 8,8 \\
\hline
\end{tabular}

их сортовые особенности. Работа же с малоизученными аборигенными сортами винограда ведется сравнительно недавно, и она показала, что наряду с общими особенностями технологии приготовления вин по белому способу, имеет место дифференцированный подход к кажАому сорту. Поэтому сорт ГрубелАа явмяется перспективным ААя расширения сортимента винограда, используемого Аля качественного виноделия, и требует Аальнейшего углубленного изучения ААя созАания технологии, позвоцяющей максимацьно раскрыть потенциац сорта и получить качественное вино с высокими органолептическими показателями. Также рекомендуется использовать сорт Грубелма в селекции, Аля создания сортов с высокими технологическими свойствами.

\section{Источники финансирования}

Не указаны.

\section{Financing source}

Not specified.

\section{Конфликт интересов}

Не заявлен.

\section{Conflict of interests}

Not declared.

\section{Список литературы / References}

1. Kamenski P.A., Sazonov A.E., Fedyanin A.A., Sadovnichy V.A. Biological collections: Chasing the ideal. Acta Naturae. 2016;8(2):6-9.

2. Wen J., Ickert-Bond S.M., Appelhans M.S. et al. Collections-based systematics: Opportunities and outlook for 2050. J. Syst. Evol. 2015;53(6):477-488. DOI 10.1111/jse.12181.

3. Anderson R.P. Harnessing the world's biodiversity data: promise and peril in ecological niche modeling of species distributions. Ann. N. Y. Acad. Sci. 2012;1260(1):66-80. DOI 10.1111/j.1749-6632. 2011.06440.x.

4. Gillespie R.G. The International biogeography society: enabling a dynamic discipline. Front. Biogeogr. 2013;5:1-5

5. Cuevas H.E., Rosa-Valentin G., Hayes C.M. et al. Genomic characterization of a core set of the USDA-NPGS Ethiopian sorghum germplasm collection: implications for germplasm conservation, evaluation, and utilization in crop improvement. BMC Genomics. 2017;18(1):108. DOI 10.1186/s12864-016-3475-7.

6. Wang C., Hu S., Gardner C., Lbbberstedt T. Emerging avenues for utilization of exotic germplasm. Trends Plant Sci. 2017;22(7): 624-637. DOI 10.1016/j. tplants.2017.04.002

7. Cook J.A., Edwards S.V., Lacey E.A. et al. Natural history collections as emerging resources for innovative education. BioScience. 2014;64(8):725-734. DOI 10.1093/ biosci/biu096.

8. Smith V.S., Blagoderov V. Bringing collections out of the dark. ZooKeys. 2012;209: 1-6. DOI 10.3897/zookeys.209.3699.

9. Павлинов И.Я. Биоразнообразие и биоколлекции: проблема соответствия / Сборник трудов Зоологического музея МГУ им. М.В. Ломоносова. - 2016. - № 54. - C. 733-786.

Pavlinov I.YA. Bioraznoobrazie i biokollekcii: problema sootvetstviya [Biodiversity and biocollections: the problem of compliance] / Sbornik trudov Zoologicheskogo muzeya MGU im. M.V. Lomonosova, 2016, № 54, pp. 733-786. (in Russian)
Ганич В.А., Наумова А.Г,

Матвеева Н.В.

10. Eiras-Dias J.E.J. Status of the Vitis national collection in Portugal. Report of a Working Group on Vitis. Rome, Italy: Bioversity International, 2008; 93-94.

11. Lacombe T. Status of the French Vitis National Collection. Report of a Working Group on Vitis. Rome, Italy: Bioversity International. 2008; 73-74.

12. Maghradze D., Maletic E., Maul E. et al. Field genebank standards for rapevines. Vitis. 2015;54: 273-279.

13. Полулях А.А., Волынкин В.А., Лиховской В.В. Генетические ресурсы винограда института «Магарач». Проблемы и перспективы сохранения // Вавиловский журнал генетики и селекции. - 2017. - № 21(6). - С. 608-616. DOI 10.18699/NJ17.276

Polulyah A.A., Volynkin V.A., Lihovskoj V.V. Geneticheskie resursy vinograda instituta "Magarach». Problemy $i$ perspektivy sobraneniya [Problems and prospects of grapevine genetic resources preservation at «Magarach» Institute] Vavilovskij zhurnal genetiki $i$ selekcii [Vavilov journal of genetics and breeding], 2017, № 21(6), pp. 608616. DOI 10.18699/NJ17.276 (in Russian)

14. Анапская ампелографическая коллекция (биологические растительные ресурсы) / Егоров Е.А., Ильина И.А., Петров В.С. и др. - Краснодар, 2018. - 194 с.

Anapskaya ampelograficheskay a kollekciya (biologicheskie rastitel'nye resursy) [Anapa ampelographic collection (biological plant resources)], Egorov E.A., Il'ina I.A., Petrov V.S. i dr. - Krasnodar, 2018, 194 p. (in Russian)

15. Наумова Л.Г., Ганич В.А. Мобилизация и сохранение генетического разнообразия сортов винограда на коллекции ВНИИВиВ им. Я.И. Потапенко // Русский виноград. - 2017.- Т. 5. - С. 40-46.

Naumova L.G., Ganich V.A. Mobilizaciva $i$ sobranenie geneticheskogo raznoobraziya sortov vinograda na kollekcii VNIIViV im. YA.I. Potapenko [Mobilization and conservation of genetic diversity of grape varieties in the collection of YA.I. Potapenko all-russian research institute for viticulture and winemaking]. Russkij vinograd. [Russian grapes], 2017, T. 5, pp. 40-46. (in Russian)

16. Jung A., Fischer C. National inventory of grape genetic resources in Germany. Interactive Ampelography and Grapevine Breeding: Collected Papers of the Int. Symp., 20-22 Sept. 2011. Krasnodar, 2012;233-236.

17. Maghradze D., Maletic E., Maul E. et al. Field genebank standards for rapevines. Vitis. 2015;54:273-279.

18. Dettweiler E. Genetic resources - Gene banks. Vitis. 1990;29:57-59.

19. Maul E., This P., Dias J.E. GENRES 081 - a basis for the preservation and utilization of Vitis genetic resources: Report of a Working Group on Vitis. First Meeting, 1214 June 2003, Palić, Serbia and Montenegro. Rome, Italy: Bioversity International, 2008;13-22.

20. Наумова Л.Г., Ганич В.А. Сохранение и изучение генофонда автохтонных донских сортов винограда на коллекции ВНИИВиВ им. Я.И. Потапенко // Магарач. Виноградарство и виноделие. - 2017. - № 1.- С. 9-13.

Naumova L.G., Ganich V.A. Sobranenie $i$ izuchenie genofonda avtohtonnyb donskib sortov vinograda na kollekcii VNIIViV im. YA.I. Potapenko [Preservation and study of gene pool of autochthonous don of grape varieties in the collection ARRIV\&W]. Magarach. Vinogradarstvo $i$ vinodelie. [Magarach. Viticulture and Winemaking], 2017, № 1, pp. 9-13. (in Russian)

21. Pelengic R., Koruza B. Slovenia grapevine germplasm. Acta Agriculturae Slovenica. 2012;99(3):429-432.

22. Li S.H., Archbold D., London J. Collection, conservation, evaluation and utilization of Vitis amurensis germplasm resources in China. Acta Hortic. 2015;1082:79-86.

23. Maul E., Tupfer R., Carka F. et al. Identification and characterization of grapevine genetic resources maintained in Eastern European Collections. Vitis. 2015;54:5-12.

24. Ильницкая Е.Т., Токмаков С.В. Изучение полиморфизма SSR-локусов южнороссийских аборигенных со- 
ртов винограда // Плодоводство и виноградарство Юга России. - 2014.- №27(3).- C. 1-6.

Il'nickaya E.T., Tokmakov S.V. Izuchenie polimorfizma SSR-lokusov yuzhnorossijskih aborigennyb sortov vinograda [Study of SSR-loci polymorphism of sauhtrussian local grape cultivars]. Plodovodstvo $i$ vinogradarstvo YUga Rossii. [Fruit growing and viticulture of the South of Russia], 2014, №27(3), pp. 1-6. (in Russian)

25. Панахов Т., Салимов В., Наджафов Д. Малораспространенные ценные сорта винограда Нахичевани // Виноделие и виноградарСтво. - 2011. - №5. - C.38-39.

Panakhov T., Salimov., Nadzhafarov D. Malorasprostranenniye tsenniye sorta vinograda Nakbichevani [Minor valuable grapevine varieties of Nakhichevan]/Vinodeliye i vinogradarstvo [Viticulture and Winemaking].-2011. - №5. - pp.38-39. (in Russian)

26. Салимов В.С. Сбор, сохранение и перспективы продолжительного использования генетических ресурсов винограда // Интерактивная ампелография и селекция винограда: Матер. междун. симпоз. - Краснодар, 2012. - С. 197-198.

Salimov V.S. Sbor, sobranenie $i$ perspektivy prodolzhitel'nogo ispol'zovaniya geneticheskih resursov vinograda [Collection, preservation and prospects for the continued use of grape genetic resources]. Interaktivnaya ampelografiya $i$ selekciya vinograda: Materialy mezhdunarodnogo simpoziuma, Krasnodar, 2012, pp. 197-198. (in Russian)

27. Аджиев А.М., Мусаев И.А., Караев М.К., Казиев М-Р.А. Аборигенные сорта винограда Дагестана как генофонд для селекции новых сортов // Мобилизация и сохранение генетических ресурсов винограда, совершенствование методов селекционного процесса: Мат. междун. научн.-практ. конф. ГНУ Всерос. НИИ виноградарства и виноделия им. Я.И. Потапенко Россельхозакадемии. - Новочеркасск: Изд-во ГНУ ВНИИВиВ им. Я.И. Потапенко, 2008.- С.10-13.

Adzhiev A.M., Musaev I.A., Karaev M.K., Kaziev M-R.A. Aborigennye sorta vinograda Dagestana kak genofond dlya selekcii nouyh sortov [Aboriginal grapes of Dagestan as a gene pool for breeding new varieties]. Mobilizaciya $i$ sobranenie geneticheskih resursov vinograda, sovershenstvovanie metodov selekcionnogo processa: Materialy mezhdunarodnoj nauchno-prakticheskoj konferencii GNU Vserossijskij NII vinogradarstva i vinodeliya im. YA.I. Potapenko Rossel'bozakademii. - Novocherkassk: Izd-vo GNU VNIIViV im. YA.I. Potapenko, 2008.- pp.10-13. (in Russian)
28. Вахтангадзе Т., Маградзе Д., Чипашвили Р., Квалиашвили В. Участие грузинских сортов в селекции винограда // Интерактивная ампелография и селекция винограда: Матер. междун. симпоз. Краснодар, 2012.- С. 7.

Vahtangadze T., Magradze D., CHipashvili R., Kvaliashvili V. Uchastie gruzinskib sortov $v$ selekcii vinograda [The participation of Georgian varieties in the selection of grapes]. Interaktivnaya ampelografiva $i$ selekciya vinograda: Materialya mezhdunarodnogo simpoziuma - Krasnodar, 2012, p. 7. (in Russian)

29. Табидзе Д.И. Грубелла кахури // Ампелография СССР. Малораспространенные сорта винограда. Т.1.- М.: Пищепромиздат, 1963.C. 385-387.

Tabidze D.I. Grubella kahuri [Grubella Kahuri]. Ampelografiya SSSR. Malorasprostranennye sorta vinograda. T.1.- M.: Pishchepromizdat, 1963.- pp. 385-387. (in Russian)

30. Лазаревский М.А. Изучение сортов винограда.- Ростов-на-Дону: Изд-во ун-та, 1963. - $151 \mathrm{c.}$

Lazarevskiy M.A. Izuchenie sortov vinograda [The study of grapes]. Rostov-na-Donu: Izd-vo Rostovskogo universiteta, 1963, 152 p. (in Russian)

31. Амирджанов А.Г., Сулейманов Д.С. Оценка продуктивности сортов винограда и виноградников: Методические указания.- Баку, 1986. $-54 \mathrm{C}$.

Amirdzhanov A.G., Suleimanov D.S. Ocenka produktivnosti sortov vinograda $i$ vinogradnikov [Evaluation of the productivity of grapes and vineyards]. Metodicheskie ukazaniya. Baku, 1986, 54 p. (in Russian)

32. Погосян С.А. Методические указания по селекции винограда. Ереван: Айастан, 1974. - 226 с.

Pogosyan S.A. Metodicheskie ukazaniya po selektsii vinograda [Recommended practices for grapevine selection]. Yerevan: Ayastan Publ., 1974, 226 p. (in Russian)

33. Сборник технологических инструкций, правил и нормативных материалов по винодельческой промышленности / под ред. Г.Г. Валуйко. - М.: Агропромиздат, 1985.-511 с.

Sbornik tekbnologicheskib instrukcij, pravil i normativnyb materialov po vinodel'cheskoj promyshlennosti [Collection of technological instructions, rules and regulatory materials for the wine industry] pod redakciej G.G. Valujko. M.: Agropromizdat, 1985, 511 p. (in Russian) 